\title{
Tretmanski pristupi ovisnosti o Internetu
}

\author{
Sabina Mandić \\ Dora Dodig Hundrić \\ Neven Ricijaš \\ Odsjek za poremećaje u ponašanju, \\ Edukacijsko-rehabilitacijski fakultet, Sveučilište u Zagrebu \\ E-mail: sabina.mandic@erf.hr
}

\begin{abstract}
Sažetak
Internet je u modernom svijetu izuzetno prisutan i često neophodan za obavljanje svakodnevnih obveza. Sredstvo je zadovoljavanja psiholoških potreba te je sastavni dio suvremene komunikacije. U tom kontekstu, ne iznenađuje da dio populacije razvija probleme povezane s njegovom prekomjernom uporabom, a koji mogu voditi i razvoju ovisnosti.

No, ne postoji jednoznačna definicija ovog problema niti precizni pokazatelji o prevalenciji i incidenciji, stoga ovisnost o Internetu još uvijek nije uvrštena kao zasebni dijagnostički entitet u međunarodne klasifikacije problema mentalnog zdravlja. Međutim, neosporna aktualnost i raširenost štetnih psihosocijalnih posljedica kod dijela populacije, doveli su do potrebe za razvojem tretmanskih intervencija.

U nedostatku domaće literature u ovom području, cilj ovog rada je ponuditi sustavan i sveobuhvatan pregled postojećih tretmanskih pristupa ovisnosti o Internetu, njihovih terapijskih temelja, ključnih izazova tretmana te dostupnih rezultata istraživanja učinkovitosti.

Autori se u zaključku reflektiraju na aktualne konceptualne i znanstvenoistraživačke izazove koji predstavljaju prepreke u razvoju tretmanskih intervencija i u zaključivanju o njihovoj učinkovitosti.
\end{abstract}

Ključne riječi: Internet, ovisnost o Internetu, bihevioralne ovisnosti, tretman

\section{Uvod}

S razvojem tehnologija došlo je do raširene uporabe Interneta u svakodnevnom životu svih dobnih skupina, a mladi se u tom kontekstu ističu kao najveći korisnici s obzirom da su od samog rođenja okruženi modernom tehnologijom (Weiser, 2001; Akin i Iskender, 2011; Rich, Tsappis i Kavanaugh, 2017; Bisen i Deshpande, 2018; Cimino i Cerniglia, 2018; Smyth, Curran i Mc Kelvey, 2018). Internet pruža izuzetno puno mogućnosti, njime se zadovoljavaju brojne psihološke potrebe, stoga ne iznenađuju podaci da trenutno u svijetu ima preko tri i pol milijarde aktivnih korisnika Interneta, pri čemu ih je oko tri milijarde aktivno na barem jednoj društvenoj mreži (Kuss i LopezFernandez, 2016; Smyth, Curran i Mc Kelvey, 2018), dok dio populacije razvija probleme povezane s prekomjernom uporabom Interneta (Dodig Hundrić, Ricijaš i Vlček, 2018).

Većina populacije intenzivno i aktivno koristi Internet, ono je normativno očekivano, a u kontekstu ovisnosti i legalno, stoga je posebno izazovno pitanje granice između funkcionalne i prekomjerne, to jest problematične uporabe koja potencijalno vodi prema razvoju ovisnosti (Brand 
i sur., 2016; Smyth, Curran i Mc Kelvey, 2018). Griffiths (2005) navodi da funkcionalna uporaba Interneta doprinosi kvaliteti života pojedinaca, odnosno Internet se koristi kako bi se zadovoljile određene potrebe ili izvršili zadaci, a kada se te aktivnosti odrade, osoba bez poteškoća prekida s njegovom uporabom te nastavlja sa svakodnevnim aktivnostima. Ovisnost o Internetu najčešće se definira kao nemogućnost kontrole korištenja Interneta koja utječe na svakodnevno funkcioniranje pojedinca, te je popraćena nemirom i iritabilnošću kada se korištenje Interneta pokuša smanjiti ili u potpunosti prekinuti (Young, 1996, 2004, 2015; Brand, Laier i Young, 2014a; Brand, Laier i Youg, 2014b; Brand i sur., 2016), čime je definicija usklađena s općim kriterijima i simptomima bihevioralnih ovisnosti kao što su preokupiranost ponašanjem, nemogućnost smanjenja ili prestanka uključenosti u ponašanje unatoč želji da se smanji ili prestane s određenim ponašanjem, zanemarivanje ostalih aktivnosti, ponavljana uporaba Interneta unatoč saznanju o postojanju psihosocijalnih problema, laganje o vremenu provedenom na Internetu, modifikacija raspoloženja, razvoj tolerancije, simptomi sustezanja, konflikti i relaps (Young, 1996, 2004, 2015; Griffiths, 2005; Brand, Laier i Young, 2014a; Brand, Laier i Youg, 2014b; Brand i sur., 2016; Zajac i sur., 2017). Pritom se u kontekstu ovisnosti o Internetu naglasak stavlja na četiri specifična obilježja: (1) ponavljana pretjerana uporaba unatoč saznanju o postojanju psihosocijalnih problema, (2) laganje o vremenu provedenom na Internetu, (3) ugrožavanje ili gubitak važne veze, posla ili obrazovne/poslovne mogućnosti zbog korištenja Interneta te (4) gubitak pojma o vremenu i zanemarivanje osnovnih životnih potreba zbog korištenja Interneta (Luo, Brennan, Wittenauer, 2015; Rumpf i sur., 2016; Zajac i sur., 2017).

Također razlikujemo generaliziranu i specifičnu ovisnost o Internetu, ovisno o tome postoji li ili ne preferirana i dominantna Internet aktivnost (Davis, 2001). Specifičnoj ovisnosti se, temeljem istraživanja i kliničkih iskustava, u posljednje vrijeme priklanja sve više znanstvenika (Starcevic, 2013; Montag i sur., 2015), a kao najčešći modaliteti navode se ovisnost o (1) online video igrama, o (2) društvenim mrežama te o (3) pornografskim sadržajima (Kuss i Griffiths, 2017; Bisen i Deshpande, 2018). lako se, kao što je ranije navedeno, u novije vrijeme sve više znanstvenika priklanja konceptu specifične ovisnosti o Internetu unutar koje se razlikuju vodeća tri modaliteta, postoji i shvaćanje nekih znanstvenika kako bi se ovisnost o Internetu i ovisnost o video igrama trebale promatrati kao zasebni entiteti, te kako bi i tretmanski pristupi trebali biti različiti (primjerice Siomos i sur., 2008; van Rooij i sur., 2010; prema Zajac i sur., 2017). Autori ovog rada se, temeljem recentnije literature o ovisnosti o Internetu, priklanjaju konceptu specifične ovisnosti o Internetu, unutar kojeg se navode različiti modaliteti ovisnosti.

Važno je istaknuti da ovisnost o Internetu još uvijek nije zasebni dijagnostički entitet u službenim međunarodnim klasifikacijama bolesti (Smyth, Curran i Mc Kelvey, 2018). No, 2018. godine ovisnost o video igrama uvrštena je u najnovije izdanje Međunarodne klasifikacije bolesti (MKB-11') kao zasebni dijagnostički entitet, a u Dijagnostičkom i statističkom priručniku za duševne poremećaje [DSM-5] (Američka psihijatrijska udruga, 2014) ovisnost o internetskim igrama uvrštena je u poglavlje "Stanja koja se razmatraju za uvrštavanje". I u ovom užem području razlikuje se nekoliko modaliteta: dominantno online, dominantno offline i nespecificirano korištenje.

Što se tiče prevalencije ovisnosti o Internetu, istraživanja pokazuju velik varijabilitet rezultata što možemo pripisati nepostojanju konsenzusa u definiranju i kriterijima ove ovisnosti (više u

1 International Classification of Diseases 11th Revision. Posjećeno 10. svibnja 2019. na mrežnoj stranici: https://icd.who.int/browse11/l-m/ en\#/http\%3a\%2f\%2fid.who.int\%2ficd\%2fentity\%2f1448597234 
Dodig Hundrić, Ricijaš i Vlček, 2018), kulturološkim i socijalnim razlikama te onim metodološkim, prije svega metodama uzorkovanja i činjenici da su, uslijed nepostojanja tzv. zlatnog standarda procjene izraženosti problema, korišteni različiti, uglavnom nestandardizirani instrumenti procjene. Primjerice, dok značajan broj istraživanja na općoj populaciji govori u prilog prevalenciji problema od 1\% do 5\% (Bakken i sur., 2009; Rumpf i sur., 2014; Sariyska i sur., 2014; Vondrackova i Šmahel, 2018), u istraživanju provedenom u devet europskih zemalja, Laconi i suradnici (2018) utvrdili su prevalenciju od $14.3 \%$ do čak $54.9 \%$. Nadalje, na uzorcima djece i mladih prevalencija se kreće od 0.8\% pa sve do 11\% (Poli i Agrimi, 2011; Rębisz i Sikora, 2016) u europskim zemljama, te od 8.1\% do $20.3 \%$ u azijskim zemljama (Ha i sur., 2006; Cao i sur., 2011). Kod populacije studenata također se bilježi raznolika zastupljenost problema, od 3.2\% (Kuss, Griffiths i Binder, 2013) pa sve do $26.3 \%$. (Fortson i sur., 2007). Drugim riječima, iako je teško egzaktnije zaključivati o samoj prevalenciji problema, neosporno je da određeni dio populacije gubi kontrolu nad korištenjem Interneta, čime narušava svoje svakodnevno psihosocijalno funkcioniranje.

Obilježja štetnih posljedica uslijed prekomjernog korištenja Interneta posebice su nam bitna u kontekstu osmišljavanja i planiranja tretmanskih intervencija. Kao neke od učestalijih navode se poremećena struktura spavanja, prekomjerna konzumacija kofeina ili opojnih sredstava, slabiji akademski i/ili poslovni uspjeh, narušeni rad imunološkog sustava, problemi u odnosima (intimnim, prijateljskim, rodbinskim), česte promjene raspoloženja, depresivnost, usamljenost, socijalna izolacija, impulzivnost te anksioznost (Young, 1999; Weiser, 2001; Young, 2004; Turel, Serenko i Bontis, 2011; Achab i sur., 2015; Zhou, Zhou i Zhu, 2016; Li i sur., 2019). Zbog same prirode ove specifične ovisnosti, može se pojaviti i kronična bol u leđima, narušena verbalna i radna memorija, glavobolja te se povećava rizik za prekomjernu tjelesnu masu (Young, 1999; Eliacik i sur., 2016; Zhou, Zhou i Zhu, 2016; Jurman i sur., 2017).

Nadalje, ovisnost o Internetu značajno je povezana i s problemima mentalnog zdravlja (Rumpf i sur., 2014; Sharma i De Sousa, 2016), te su konkretno socijalna anksioznost, depresija i ADHD (deficit pažnje/hiperaktivni poremećaj) tri najčešće dijagnoze u komorbiditetu s ovisnosti o Internetu (Yen i sur., 2007a; Weinstein i Lejoyeux, 2010; Achab i sur., 2015; Luo i sur., 2015; Prizant-Passal i sur., 2016; Rumpf i sur., 2016; Vondrackova i Šmahel, 2018; Kuss i Pontes, 2019). Carli i suradnici (2013) su analizirajući 20 studija utvrdili preklapanje ovisnosti o Internetu s ADHD-om u 100\% slučajeva, depresijom u njih $75 \%$, u oko $60 \%$ studija s hostilnošću, agresijom i opsesivno-kompuIzivnim poremećajem te u $57 \%$ studija s anksioznošću. No, danas se još uvijek među znanstvenicima i kliničarima vode debate o smjeru tih povezanosti, odnosno je li ovisnost o Internetu uzrok ili posljedica prisutnih mentalnih poremećaja, radi li se o poremećajima koji u podlozi imaju iste mehanizme razvoja ili je tako visok komorbiditet "precijenjen“ uslijed metodoloških ograničenja (Aboujaoude i sur., 2006; Ko i sur., 2012; Winkler i sur., 2013; Seyrek i sur., 2016). Odgovor na ta kompleksna pitanja vrlo vjerojatno nije jednoznačan, te nam ga mogu ponuditi longitudinalne studije kojih još uvijek nedostaje. Bilo da je razvijena ovisnost dio etiologije ili posljedica drugih problema mentalnog zdravlja, nedvojbeno je da je njihova međusobna povezanost izuzetno bitna i neizostavna u kontekstu tretmanskih intervencija.

Slijedom navedenog, neosporna je aktualnost ovog problema s pratećim spektrom štetnih psihosocijalnih posljedica, što je rezultiralo i potrebom za razvojem učinkovitih tretmanskih intervencija. Stoga su ciljevi ovog rada pružiti sustavan i sveobuhvatan pregled i kritički osvrt na 
postojeće tretmanske pristupe ovisnosti o internetu, njihove terapijske temelje, ključne izazove tretmana te dostupne rezultate istraživanja njihove učinkovitosti.

\section{Tretman ovisnosti o Internetu}

lako se posljednjih godina razvijaju raznoliki tretmanski pristupi (Kuss, 2016; Mihajlov i Vejmelka, 2017; Vondrackova i Šmahel, 2018), studije o njihovoj učinkovitosti i dalje su rijetke (Mihajlov i Vejmelka, 2017). Tretman ovisnosti o Internetu ima specifičnosti koje predstavljaju određena ograničenja i/ili izazove, a prije svega se to odnosi na otežanu modifikaciju postojećih tretmanskih programa ovisnosti (primjerice o psihoaktivnim tvarima i/ili o kockanju) i korištenje njihovih postavki u tretmanu ovisnosti o Internetu. Psihoaktivne tvari imaju jasan (i)legalni status, konzumaciju i biološku podlogu ovisnosti uslijed unošenja kemijskih spojeva, kao što je i kockanje aktivnost u koju se pojedincac uključuje s ciljem zadovoljavanja potrebe za zabavom i/ili uzbuđenjem. Navedena sredstva/predmeti ovisnosti nisu nužni u svakodnevici, stoga je glavna premisa u njihovom tretmanu ostvarivanje apsolutne apstinencije od tvari i/ili ponašanja o kojemu je osoba ovisna (Pearson i sur., 2012). No, kod Interneta bi potpuna apstinencija u velikoj mjeri bila kontradiktorna s uobičajenim i očekivanim psihosocijalnim funkcioniranjem. Ujedno se radi i o ponašanju koje nije ilegalno, dapače, normativno je i očekivano, stoga je sam cilj tretmana različit, usmjerava se na kontroliranu i uravnoteženu uporabu Interneta te izbjegavanje adiktivnih aplikacija (Young, 1999; Cash i sur., 2012; Pontes, Kuss i Griffiths, 2015; Young, 2015).

Suvremeni tretmanski pristupi mogu se podijeliti u tri velike skupine: (1) psihološki, (2) farmakološki te (3) kombinirani pristup, koji objedinjuje psihološki i farmakološki (Cash i sur., 2012; Mihajlov i Vejmelka, 2017; Kuss i Pontes, 2019), a koji bi, prema vodećim stručnjacima u području, trebao dominirati (Przepiorka i sur., 2014; Pontes, Kuss i Griffiths, 2015; Vondrackova i Šmahel, 2018). U ovom radu bit će prikazani tretmanski pristupi i programi za koje je provedena evaluacija učinkovitosti. S obzirom da je razvoj tretmana ovisnosti o Internetu, kao što je ranije navedeno, u svojim počecima, evaluiranih programa nema mnogo te će se stoga prikazati dostupni evaluirani programi neovisno o tome radi li se o tretmanu usmjerenom generalno na ovisnost o Internetu ili na specifični modalitet te ovisnosti. Ključni rezultati komentirani su u kontekstu kriterija znanstveno-utemeljenih tretmana koje predlažu Chambless i suradnici (1998; prema Zajac i sur., 2017), a temeljem kojih se oni mogu kategorizirati u tri skupine:

I) eksperimentalni — još uvijek nema nedovoljno dokaza koji bi potvrdili je li program vjerojatno učinkovit ili dobro uspostavljen znanstveno-utemeljeni program;

II) vjerojatno učinkoviti - minimalno dva eksperimentalna istraživanja moraju potvrditi učinkovitost tretmana u odnosu na kontrolnu skupinu;

III) dobro uspostavljen (znanstveno-utemeljeni) program — dva ili više eksperimentalna istraživanja moraju utvrditi učinkovitost programa u odnosu na farmakoterapiju, placebo, u odnosu na neki drugi program ili se mora pokazati učinkovitim kao već neki od postojećih tretmana. Ti učinci moraju biti potvrđeni od strane minimalno dva istraživača ili istraživačka tima. 


\section{Psihološki pristupi}

Najčešći psihološki pristupi tretmana ovisnosti o Internetu uključuju tehnike kognitivno-bihevioralne terapije (KBT), obiteljsku i realitetnu terapiju, te korištenje metoda motivacijskog intervjuiranja (Cash i sur., 2012; King i sur., 2012; Young, 2015; Rumpf i sur., 2016; Mihajlov i Vejmelka, 2017; Shen, 2018; Vondrackova i Šmahel, 2018). Pojedine tretmanske intervencije temelje se na samo jednom pristupu, dok ih neke kombiniraju.

Kognitivno-bihevioralni pristup (KBT), kao što je to slučaj i s drugim problemima u ponašanju, najčešći je pristup u tretmanu ovisnosti o Internetu (Cash i sur., 2012; Shad Kaneez i sur., 2013; Mihajlov i Vejmelka, 2017; Greenfield, 2018; Malak, 2018; Vondrackova i Šmahel, 2018). Glavni je cilj naučiti osobu prepoznati i kontrolirati vlastite misli i osjećaje koje mogu biti štetne za svakodnevno funkcioniranje te mogu potaknuti "bijeg” iz realnog u virtualni svijet (Huang, Li i Tao, 2010; Young, 2011a; Przieporka i sur., 2014; Greenfield, 2018; Vondrackova i Šmahel, 2018). Tretmanom, osobe ovisne o Internetu uče konstruktivno rješavati svoje probleme i sprječavati sebe u ponovnom nefunkcionalnom korištenju Interneta (Young, 2007; Przepiorka i sur., 2014). Tretman uglavnom uključuje tehnike učenja vještina upravljanja vremenom, prepoznavanja potencijala i štetnih učinaka Interneta, podizanja samosvijesti i svijesti o drugima, identificiranja okidača koji vode ka prekomjernoj upotrebi Interneta (određene aplikacije, emocionalna stanja, kognitivne distorzije, životni događaji i slično), učenja samoregulacije emocija i kontrole nagona za korištenjem Interneta, razvoja i unaprjeđivanja komunikacijskih i socijalnih vještina, rad na strategijama nošenja sa stresnim situacijama i razvoj interesa za druge aktivnosti slobodnog vremena koje ne uključuju Internet (Orzack i sur., 2006; Young, 2007; Zhong i sur., 2009, prema Huang, Li i Tao, 2010; Du, Yiang i Vance, 2010).

Prvi strukturirani sveobuhvatni tretmanski program koji počiva na kognitivno-bihevioralnom pristupu, CBT-IA (eng. Cognitive Behavioral Therapy — Internet Addiction), razvila je Kimberly Young (2011). Glavni ciljevi CBT-IA modela usmjereni su na reduciranje simptoma ovisnosti osnaživanjem kontrole impulsa, promjenom kognitivnih distorzija te adresiranjem osobnih i situacijskih čimbenika povezanih s prekomjernom uporabom Interneta. Ukupno trajanje programa je oko 3 mjeseca, odnosno 12 tjednih susreta podijeljenih u tri faze: 1) modifikacija ponašanja, 2) kognitivno restrukturiranje te 3) terapija smanjenja štete (eng. harm reduction therapy) (Young, 2011a; Rowicka, 2016; Malak, 2018). Tijekom prve faze, glavni cilj je postepeno smanjivati kognitivnu i bihevioralnu preokupaciju Internetom kroz pisanje dnevnika uporabe, reorganizacija načina korištenja Interneta (brisanje omiljenih stranica ili aplikacija, postavljanje ciljeva vezanih uz ograničavanje dnevne uporabe Interneta i slično). Druga je faza usmjerena na iskrivljene misli i sliku o sebi (realnu i virtualnu), a fokus je stavljen na učenje vještina nošenja sa stresnim situacijama, metode rješavanja problema, praćenje vlastitih misli i slično. Također, naglasak se stavlja na aktivno uključivanje i preuzimanje odgovornosti za vlastiti napredak $u$ tretmanu. $U$ posljednjoj fazi tretmana identificiraju se osobni (psihološki) i situacijski čimbenici povezani s razvojem ovisnosti o Internetu (npr. depresivna i anksiozna simptomatologija, rutine i slično). Slijedom navedenog, u ovoj fazi se identificiraju snage i kapacitet osobe za promjenu, pomaže im se u pronalasku posla i obnavljanju veza s drugima (Young, 2011a; Rowicka, 2016; Malak, 2018). Youngova je 2013. godine testirala učinkovitost ovog programa koristeći IADQ (eng. Internet Addiction Diagnostic Questionnaire, Young, 1998) i ček-listu očekivanih ponašanja po završetku tretmana (primjerice: pridržavanje planiranog vremena provedenog na 
Internetu, učinkovitost u obavljanju školskih/poslovnih obveza, komunikacija s drugima uživo, a ne preko aplikacija i slično). Rezultati su pokazali pozitivne pomake kod pacijenata na oba instrumenta, a učinci su se zadržali i nakon šestomjesečnog praćenja (Young, 2013).

Još jedan strukturirani tretmanski program ovisnosti o Internetu i video igrama (eng. ShortTerm Treatment for Internet and Computer Game Addiction [STICA]) temeljen na kognitivno-bihevioralnom pristupu razvili su Wölfling i suradnici (2013, prema Kuss i Pontes, 2019). Program se sastoji od kombinacije grupnih i individualnih susreta kroz ukupno 4 mjeseca (Jäger i sur., 2012). Na grupnim susretima prorađuju se teme poput identifikacije okidača, uči se suzdržavanje od adiktivnih aplikacija ili igara, provodi se psihoedukacija, razvija se individualni model razvoja ovisnosti (kako je došlo do ovisnosti, kako osoba reagira na određene situacije, koje su posljedice i slično), prevencija relapsa te se po završetku radi refleksija na uspjeh tretmana i ostvarene promjene (Wölfling i sur., 2014). Rezultati evaluacije kod osoba koje su završile tretman ( $n=42)$ pokazuju njegovu učinkovitost: značajno su smanjeni simptomi ovisnosti o Internetu (preokupacija, tolerancija, gubitak kontrole i slično), smanjeno je vrijeme provedeno na Internetu te je zabilježeno i smanjenje sekundarnih negativnih posljedica kao što su problemi s obitelji ili prijateljima te učinkovitost na poslu ili u školi (Wölfling i sur., 2014).

S obzirom na važan doprinos obiteljskih čimbenika razvoju ove ovisnosti, nužne su i intervencije temeljene na obiteljskoj terapiji (Yen i sur, 2007b), pogotovo kada se radi o adolescentima. Obiteljska terapija može uključivati psihoedukaciju članova obitelji, savjetovanje, učenje strategija nošenja s ljutnjom i gubitkom povjerenja, razumijevanje procesa promjene i oporavka, prepoznavanje okidača, te važnost postavljanja adekvatnih granica (Huang, Li i Tao, 2010). Učinkovitost obiteljske terapije najčešće je provjeravana kod mladih ovisnika o psihoaktivnim tvarima (Liu i sur., 2015), dok su programi vezani uz ovisnost o Internetu u počecima svojeg razvoja. Liu i suradnici (2015) proveli su grupni tretman temeljen na obiteljskoj terapiji (eng. multi-family group approach) za ukupno $n=92$ sudionika (adolescenti koji zadovoljavaju kriterije za ovisnost o Internetu i njihovi roditelji) koji su bili podijeljeni u interventnu i kontrolnu skupinu. Rezultati ukazuju na statistički značajnu razliku između navedenih skupina na način da sudionici iz interventne skupine postižu pozitivne pomake u kontekstu smanjenja simptoma ovisnosti o Internetu, kvalitetnije komunikacije s roditeljima i adekvatnijih načina zadovoljavanja potreba u stvarnom životu, a ti pomaci zadržali su se i nakon tromjesečnog praćenja (Liu i sur., 2015).

Realitetna terapija (RT) pristup je utemeljen na teoriji izbora koja pretpostavlja odgovornost za vlastite osjećaje, mišljenje i ponašanja, te ih ljudi sami izabiru (Kim, 2007; 2008). Slijedom navedenog, glavni cilj je potaknuti pojedince izabrati promjenu vlastitog stanja uz pomoć terapeuta. Provjeravajući učinkovitost realitetne terapije, Kim (2008) je proveo istraživanje s ukupno $n=25$ studenata koji su zadovoljavali kriterije za ovisnost o Internetu i koji su slučajnim odabirom podijeljeni u interventnu i kontrolnu skupinu. Realitetna terapija pokazala se učinkovitom u smanjenju simptoma ovisnosti i povećanju samopouzdanja kod studenata iz tretmanske skupine, dok kod onih iz kontrolne nisu zabilježeni efekti.

Kombinirani psihološki pristupi u tretmanu ovisnosti o Internetu objedinjavaju nekoliko psiholoških pristupa i nekoliko modaliteta provedbe (individualno - grupno; hospitalizacija - dnevno liječenje i slično) u jedan tretmanski pristup. Dodana vrijednost i prednost ovakvog pristupa u 
kreiranju tretmanskih programa je međusobna nadopuna pojedinih psiholoških tehnika i terapijskih pravaca (Huang, Li i Tao, 2010), a kao jedini kombinirani psihološki program o kojem postoji dostupna literatura i za kojeg je napisan protokol o provedbi te detaljni program rada navodi se PIPATIC (eng. Individualized psychotherapy program for addiction to information and communication technologies) program za mlade od 12 do 18 godina ovisne o on-line video igrama (Torres-Rodríguez, Griffiths i Carbonell, 2018). Program se sastoji od ukupno šest modula koji se odvijaju kroz šest mjeseci (22 tjedna susreta u trajanju od 45 minuta) i usmjereni su i prema pojedincu i prema njegovoj obitelji. Glavni terapijski pravac u podlozi PIPATIC programa je kognitivno-bihevioralni, zbog njegove empirijski dokazane učinkovitosti, a osim njega koriste se i motivacijsko intervjuiranje, strategije samoregulacije, obiteljska terapija, terapija usmjerena na rješavanje problema i traženje adekvatnih rješenja te psihoedukacija. Glavni ciljevi su razvoj funkcionalnog korištenja video igara i Interneta općenito, poboljšavanje općeg kliničkog stanja adolescenata te multidimenzionalni pristup adolescentima stavljajući naglasak na intrapersonalne i interpersonalne potrebe, te na potrebe obitelji (Torres-Rodríguez i Carbonell, 2017; Torres-Rodríguez, Griffiths i Carbonell, 2018). Preliminarni rezultati učinkovitosti pokazuju pozitivne efekte, posebno u smanjenju simptoma ovisnosti i vremena provedenog igrajući video igre, te ostalih psihičkih stanja ukoliko postoji komorbiditet, kao i poboljšano opće funkcioniranje pojedinca (odnosi s drugima, odnosi s obitelji, bolji akademski uspjeh i slično) (Torres-Rodríguez i sur., 2017).

Orzack i suradnici (2006) koristili su elemente kognitivno-bihevioralne terapije, motivacijskog intervjuiranja i pristupa spremnosti na promjenu (eng. Readiness to Change $[\mathrm{RtC}]$ ) u grupnoj terapiji s n=35 muškaraca na liječenju zbog problematičnog seksualnog ponašanja kao posljedice korištenja Interneta. Nakon 16 grupnih susreta, pacijenti su ostvarili pozitivne pomake općenito što se tiče kvalitete života, a smanjili su se i njihovi depresivni simptomi. No, razina problematične uporabe Interneta nije se promijenila - svi pacijenti uključeni u tretman i nakon 16 susreta u velikoj su mjeri koristili Internet i iskazivali rizična seksualna ponašanja povezana s korištenjem Interneta (Orzack i sur., 2006). Shek, Tang i Lo (2009) testirali su učinkovitost savjetodavnog programa ovisnosti o Internetu namijenjenog mladima. Program je trajao od 15 do 19 mjeseci (ovisno o potrebama pojedinog sudionika), temeljio se na kognitivno-bihevioralnoj terapiji, motivacijskom intervjuiranju te na pristupu spremnosti na promjenu, provodio se individualno i grupno te je uključivao i obiteljsko savjetovanje. Rezultati evaluacije pokazali su smanjivanje simptoma ovisnosti o Internetu po završetku programa te uglavnom pozitivnu percepciju učinkovitosti programa od strane polaznika (Shek, Tang i Lo, 2009).

Du, Yiang i Vance (2010) kreirali su grupni program temeljen na kognitivno-bihevioralnoj terapiji i psihoedukaciji za adolescente ovisne o Internetu, u koji se uključuju i njihovi roditelji i nastavnici. Ukupno je $n=56$ adolescenata sudjelovalo $u$ istraživanju učinkovitosti tog programa, pri čemu je njih $n=32$ raspoređeno $u$ interventnu, a $n=24$ u kontrolnu skupinu. Nakon šestomjesečnog praćenja primijećena je smanjena uporaba Interneta u obje skupine, a rezultati ukazuju na dodatne značajne pozitivne pomake u interventnoj grupi što se tiče razvoja vještina organiziranja vremena i smanjenja simptoma ovisnosti (Du, Yiang i Vance, 2010).

U Fall Cityju u Washingtonu se 2009. godine otvorio prvi centar za liječenje ovisnosti o Internetu (za sve dobne skupine) nazvan reSTART: Internet Addiction Recovery Program (Cash i sur., 2012; Shek, Yu i Sun, 2016). ReSTART je bolnički program koji, između ostalih pristupa, integrira 
tzv. "detoksikaciju” od tehnologije, program 12 koraka, kognitivno-bihevioralnu terapiju, terapiju životinjama, motivacijsko intervjuiranje, mindfulness (usredotočenu svjesnost), individualnu te grupnu psihoterapiju. Evaluacijom programa s odraslim osobama $(n=19)$ utvrđeni su pozitivni pomaci kod $74 \%$ sudionika u odnosu na bolje opće kliničko stanje, kvalitetnije interpersonalne odnose te na smanjenje subjektivne nelagode (Cash i sur., 2012; Shek, Yu i Sun, 2016).

S obzirom da je kod velikog broja ovisnika motivacija za promjenom često izuzetno niska (Greenfield, 2018), kao sastavni dio psiholoških pristupa tretmanu (bilo zasebnih ili kombiniranih), koriste se tehnike motivacijskog intervjuiranja. Time se pojačava intrinzična motivacija za promjenom na način da se istražuje i radi na ambivalenciji osobe te se na konstruktivan način konfrontira klijenta s ciljem izazivanja promjene (Miller i Rollnick, 2002, prema Cash i sur., 2012; Young, 2015, Greenfield, 2018). Motivacijsko intervjuiranje često se koristi u tretmanu kao metoda povećavanja motivacije, a kada se dođe do određene razine, tretman se nastavlja na postavkama ostalih psiholoških pristupa (Young, 2011b; Young, 2015).

lako je za sve navedene programe provedena evaluacija učinkovitosti, a rezultati ukazuju na napredak i smanjivanje problema povezanih s korištenjem Interneta, još uvijek nijedan od njih ne zadovoljava kriterije za "vjerojatno učinkovite" ili za "dobro uspostavljene znanstveno-utemeljene" programe kako ih opisuju Chambless i suradnici (1998; prema Zajac i sur., 2017). Prema toj kategorizaciji, svi programi ulaze u kategoriju „eksperimentalnih" zbog nepostojanja dovoljne količine znanstveno-utemeljenih dokaza o njihovoj učinkovitosti, na što utječu i brojna metodološka ograničenja kao što su primjerice nepostojanje kontrolne skupine, mali i prigodan uzorak i slično.

\section{Farmakološki pristup}

Farmakološki pristup u liječenju ovisnosti o Internetu vrlo se rijetko koristi kao jedini, već se kombinira s psihološkim pristupom (Cash i sur., 2012). Temelji za uporabu lijekova počivaju na rezultatima neurobioloških istraživanja koja pokazuju kako se kod ovisnosti o Internetu sustav nagrađivanja u mozgu mijenja na jednak način kao i kod ovisnosti o psihoaktivnim tvarima (Di Chiara i Bassareo, 2007; Ko i sur., 2009; Liu i sur., 2010; Balodis i sur., 2012; Blum i sur., 2012), ali i na visokom komorbiditetu ovisnosti o Internetu s drugim problemima mentalnog zdravlja (Camardese i sur., 2012; Ko i sur., 2012). No, iako je broj neurobioloških istraživanja ovisnosti o Internetu nedostatan, te ne daje jednoznačne informacije o najboljem izboru farmakološkog tretmana (Camardese i sur., 2015), činjenica je da se, unatoč potrebi daljnjih empirijskih provjera, neurobiološki etiološki čimbenici svakako moraju uzeti u obzir. Uslijed toga, farmakološki pristup je kod dijela populacije neophodan, s primarnim ciljem smanjenja drugih problema mentalnog zdravlja, što posljedično doprinosi smanjenju problema povezanih s prekomjernom uporabom Interneta (Camardese i sur., 2012).

Zbog velike sličnosti s drugim ovisnostima, ali i s opsesivno-kompulzivnim poremećajem te poremećajem kontrole impulsa, farmakološki pristup kod ovisnosti o Internetu temelji se na smjernicama i preporukama za navedena psihička stanja (Cash i sur., 2012; Przepiorka i sur., 2014; Mihajlov i Vejmelka, 2017), a kao najčešće korišteni lijekovi navode se antidepresivi, antipsihotici, psihostimulansi, antagonisti opioidnih receptora, antagonisti glutamata i stabilizatori raspoloženja (Camardese i sur., 2012; Przepiorka i sur., 2014; Camardese i sur., 2015). 
Česta uporaba antidepresiva ne iznenađuje s obzirom na već spomenuti komorbiditet depresivnosti i ovisnosti o internetu. Kao najčešći lijekovi navode se Escitalopram i Bupronion (Camardese i sur., 2012; Cash i sur., 2012; Przepiorka i sur., 2014; Camardese i sur., 2015), a istraživanja provjere njihove učinkovitosti pokazuju samo kratkoročni utjecaj na redukciju online aktivnosti i smanjenje depresivnih simptoma, koji se prema nekim studijama po završetku tretmana nisu dugoročno zadržali (Dell'Osso i sur., 2008; Han i Renshaw, 2012). U onim studijama u kojima su pozitivni pomaci bili stabilni, autori zaključuju o potrebi daljnjih istraživanja zbog brojnih istraživačkih ograničenja (Sattar i Ramaswamy, 2004, prema Camardese i sur. 2012; Han i sur., 2009), te činjenice da se s vremenom, kao posljedica uzimanja, mogu pojaviti promjene raspoloženja s maničnim epizodama u kojima su osobe u većem riziku za upuštanje u ovisnička ponašanja (Goldberg i Whiteside, 2002).

Zbog komorbiditeta s opsesivno-kompulzivnim poremećajem, u farmakološkom tretmanu koriste se i atipični antipsihotici koji smanjuju dopaminergičku i serotonergičku transmisiju u mozgu (Słowiński i sur., 2011), a kao najčešći navode se Kvetiapin, Risperidon i Olanzapin (Przepiorka i sur., 2014; Camardese i sur., 2015). Istraživanja pokazuju učinkovitost navedenih lijekova u smanjivanju opsesivnih i kompulzivnih simptoma koji posljedično mogu utjecati na razvoj i održavanje ovisnosti (Hollander i sur., 2003; Bystritsky i sur., 2004; Denys i sur., 2004; Maina i sur., 2008). Kao dokaz koji govori u prilog tome navodi se primjer 23-godišnje djevojke s razvijenom ovisnošću o Internetu kod koje je uporaba antipsihotika pokazala učinkovitost i nakon četveromjesečnog praćenja (Atmaca, 2007). No, uzevši u obzir da je riječ o analizi slučaja (eng. case-study), potrebno je dodatno i sustavno istražiti ulogu antipsihotika u liječenju ovisnosti o Internetu (Camardese i sur., 2012).

Kod djece i mladih s deficitom pažnje/hiperaktivnim poremećajem (ADHD) koji zadovoljavaju i kriterije za ovisnost o Internetu, često se upotrebljavaju i psihostimulansi, a kao najčešći navodi se metilfenidat, koji dokazano umanjuje simptome ADHD-a (Quai, 1997, prema Przepiorka, 2014; Yen i sur., 2007a). Rezultati istraživanja učinkovitosti ovog lijeka na smanjenje prekomjerne uporabe Interneta pokazuju pozitivne efekte na način da su reducirani i simptomi prekomjerne upotreba Interneta i ADHD-a (Han i sur., 2009).

Antagonisti opioidnih receptora i antagonisti glutamata još uvijek nisu testirani u odnosu na ovisnost o Internetu (Camardese i sur., 2012; Przepiorka i sur., 2014), no antagonisti glutamata, točnije memantin, pokazuje učinkovitost kod tretmana ovisnika o kockanju (Grant i sur., 2010). Stabilizatori raspoloženja često se koriste kod osoba kod kojih se preklapaju bipolarni poremećaj i ovisnost o Internetu, primarno zbog regulacije disfunkcije u dopaminergičkim putevima i abnormalnosti prefrontalnog korteksa koje su karakteristične za oba navedena stanja (Caldiroli, Serati i Buoli, 2018), a s time u vezi posljedično dolazi do smanjenja simptoma ovisnosti o Internetu. Litij i valproat pokazali su se učinkovitima u liječenju ovisnosti o kockanju (Pallanti i sur., 2002), no njihova učinkovitost još uvijek nije testirana u odnosu na ovisnost o Internetu (Camardese i sur., 2012).

Slično kao i kod tretmana unutar psihološkog pristupa, nijedan od navedenih farmakoloških tretmana ne zadovoljava kriterije za "vjerojatno učinkovite" ili za "dobro uspostavljene znanstveno utemeljene" programe (Chambless i sur., 1998; prema Zajac i sur., 2017), već se radi o „eksperimentalnim" programima. 


\section{Kombinirani pristupi}

Neki autori navode kako je kombinacija psihološkog i farmakološkog pristupa najučinkovitija u smanjenju simptoma ovisnosti o Internetu, posebice u slučajevima komorbiditeta s drugim problemima mentalnog zdravlja (Winkler i sur., 2013; Przepiorka i sur., 2014; Pontes, Kuss i Griffiths, 2015). Kim i suradnici (2012) proveli su istraživanje kojem je glavni cilj bilo testiranje učinkovitosti kognitivno-bihevioralne terapije u kombinaciji s Bupropionom u liječenju komorbiditeta ovisnosti o online video igrama i depresije kod adolescenata. Ukupno je $n=65$ adolescenata sudjelovalo $u$ istraživanju ( $n=32$ u interventnoj, a $n=33$ u kontrolnoj skupini) pri čemu su svi dobivali farmakoterapiju, a mladi iz interventne su dodatno bili uključeni i u kognitivno-bihevioralni tretman. Testirani su po završetku osmotjednog tretmana i ponovno 4 tjedna kasnije, a rezultati ukazuju na smanjenje simptoma ovisnosti o Internetu, smanjenje anksiozne simptomatologije i veće zadovoljstvo životom kod interventne u odnosu na kontrolnu skupinu. Depresivni simptomi su se podjednako smanjili kod obje skupine, odnosno nije utvrđena statistički značajna razlika. Autori zaključuju u prilog učinkovitosti ovako postavljenog tretmana, posebice na području smanjenja vremena igranja video igara, smanjenja anksioznosti i povećanju zadovoljstva vlastitim životom.

U istraživanju učinkovitosti tretmana ovisnosti o Internetu u komorbiditetu s anksioznošću, a koji je kombinirao kognitivno-bihevioralni i farmakološki pristup, Santos i sur. $(2016,2017)$ pokazuju kako su, po završetku tretmana, smanjeni simptomi oba poremećaja, kao i vrijeme provedeno na Internetu, te su se sudionici bolje nosili i suočavali s problemima (konkretno, Internet im je u manjoj mjeri bio strategija bijega od problema).

\section{Ostali modaliteti tretmana}

Osim ranije navedenih pristupa, u posljednje se vrijeme razvijaju i neki specifični oblici/modaliteti tretmana ovisnosti o Internetu, a sve s ciljem širenja lepeze dostupnih pristupa koji bi mogli najbolje odgovarati potencijalnim korisnicima. Neki od njih su socijalno i kulturalno vrlo specifični kao što su primjerice tzv. „boot” kampovi koji se šire na azijskom području te su primarno namijenjeni adolescentima (Stone, 2009; Flisher, 2010). Tretman u takvim kampovima ima obilježja vojničkog pristupa, a kao glavne metode koriste se tjelovježba, treninzi raznih sportova, čitanje, obiteljska i bihevioralna terapija te farmakoterapija, pri čemu su korisnici potpuno isključeni od "vanjskog svijeta" (adolescenti su bez mobitela, bez pristupa Internetu i tehnologiji općenito) (Stone, 2009). Važno je napomenuti kako postoje brojni stručni članci i snimljeni dokumentarni filmovi koji opisuju navedene "boot kampove", ali još uvijek ne postoji dovoljan broj znanstvenih studija pisanih na engleskom jeziku koje bi dokazale učinkovitost, ali i opisale potencijalne neželjene štetne učinke ovakvog pristupa, posebno u kontekstu činjenice da se korisnici u nekom trenutku moraju uključiti u svakodnevni život u kojem je Internet neminovan i često neophodan.

S razvojem digitalnih tehnologija, započeo je i intenzivan razvoj njihove uporabe u psihosocijalnim intervencijama koje se usmjeravaju na mentalno zdravlje, a posljednjih se nekoliko godina sve više primjenjuju i u tretmanu ili kao podrška tretmanu (Richards, 2013; Fairburn i Patel, 2017). Kao jedan od najnovijih primjera korištenja moderne tehnologije u tretmanu ovisnosti o Internetu navodi se terapija virtualnom stvarnošću (eng. virtual reality therapy [VRT]) (Zhang i Ho, 2017), koja zbog svojih kreativnih mogućnosti i inovativnosti može biti jedan od potencijalnih načina 
povećavanja učinkovitosti i smanjivanja odustajanja od tretmana, posebice kod adolescenata. Park i suradnici (2016) su temeljem rezultata neurobioloških istraživanja o promjenama u sustavu nagrađivanja u mozgu uslijed razvoja ovisnosti o Internetu pretpostavili kako korištenje virtualne realnosti može poboljšati funkcioniranje navedenog sustava. Rezultati ukazuju na njegovu učinkovitost u ponovnom uspostavljanju ravnoteže u sustavu nagrađivanja u mozgu, što je posljedično dovelo i do smanjenja simptoma ovisnosti o Internetu.

Osim navedenog, brojni znanstvenici i praktičari ulažu napore u razvoj online tretmana ovisnosti o Internetu, kao što su primjerice online individualna kognitivno-bihevioralna terapija ili motivacijsko intervjuiranje (Rowicka, 2016), ili pak intervencije temeljene na psihoinformatici, kao što su aplikacije koje mjere vrijeme provedeno na Internetu, te najčešće posjećene aplikacije kojima bi se kontrolirala uporaba Interneta (Montag, Reuter i Markowetz, 2015). O ovakvim intervencijama postoje brojni tekstovi na internetskim stranicama, no znanstvenih radova istraživanja učinkovitosti još uvijek nedostaje. Stoga se nameće pretpostavka kako je moderne tehnologije još uvijek adekvatnije koristiti kao svojevrsno „pojačanje“ ili kao integrirani dio ranije navedenih oblika tretmana, nego kao samostalnu intervenciju, iako je uporaba tehnologije u tretmanu ovisnosti o Internetu vrlo vjerojatno smjer budućeg razvoja. U prilog tome, kao i široj društvenoj svjesnosti o prekomjernom korištenju Interneta, govori nam i činjenica da svi moderni mobilni uređaji imaju integrirane aplikacije pomoću kojih korisnici mogu pratiti vrijeme provedeno online (npr. Digital Wellbeing [digitalna dobrobit], Screen Time, Social Fever, AppDetox, My Addictionmeter i mnoge druge) i time osvijestiti, te potencijalno prevenirati, prekomjerno korištenje Interneta. U skorijoj budućnosti možemo očekivati dinamične i kreativne intervencije u području tehnologija, a čija će se učinkovitost moći i empirijski provjeriti.

\section{Kritički osvrt i aktualni izazovi}

Nedvojben je značajan porast korištenja Interneta posljednjih godina, čime su se javili i psihosocijalni problemi povezani s njegovim korištenjem. Stoga ne čudi činjenica kako se u novije vrijeme sve veća pozornost znanstvenika i praktičara skreće upravo na razvoj tretmanskih intervencija, a kako bi se pomoglo pojedincima koji zbog prekomjerne i nefunkcionalne uporabe Interneta doživljavaju negativne psihosocijalne posljedice. Intervencije se razvijaju u različitim komplementarnim smjerovima, pri čemu je naglasak na psihološkom i kombiniranom pristupu koji su, prema dosad dostupnim empirijskim spoznajama, najučinkovitiji.

No, osvrnemo li se kritički na dostupne informacije i spoznaje u ovom području, uočavamo brojne izazove i/ili potencijalna ograničenja koja je potrebno uzeti u obzir.

Za potrebe ovog rada podijelit ćemo ih u (1) konceptualne izazove vezane uz definiranje samog pojma, kriterije i time postojeće instrumente procjene, te (2) one vezane uz obilježja i dostupne empirijske spoznaje o učinkovitosti tretmana ovisnosti o Internetu.

Kada je riječ o (1) konceptualnim izazovima, prije svega je nužno u obzir uzeti činjenice da još uvijek ne postoji konsenzus u operacionalizaciji i definiranju ovisnosti o Internetu kao poremećaja mentalnog zdravlja (Mihajlov i Vejmelka, 2017; Dodig Hundrić, Ricijaš i Vlček, 2018). Drugim riječima, ne postoje standardizirani kriteriji za utvrđivanje samog problema, na što se nadovezuje i 
činjenica da ovisnost o Internetu još uvijek nije kategorizirana kao zaseban dijagnostički entitet u psihijatrijskim priručnicima i međunarodnim klasifikacijama bolesti (Pontes, Kuss i Griffiths, 2015). Navedeno onemogućava postavljanje dijagnoze, a potencijalno i rano prepoznavanje problema te upućivanje u tretman. Nadalje, ne postoje standardizirani instrumenti (Vondrackova i Šmahel, 2018), niti oni usmjereni probiru populacije, niti oni usmjereni utvrđivanju razine problema i vrsta štetnih psihosocijalnih posljedica. Ova okolnost također je posljedica prethodno navedenih izazova, prije svega nejasnoća u samom definiranju problema i nepostojanja jasnih kriterija za utvrđivanje prisutnosti problema. Posljedično, uz izazov prepoznavanja pojedinaca kojima je potrebna intervencija, nedostatak adekvatnih instrumenata dovodi i do teškoća u utvrđivanju zastupljenosti problema u općoj populaciji. Stoga ne čudi da kod empirijskih pokazatelja uočavamo velik varijabilitet rezultata i još uvijek ne možemo jednoznačno govoriti o prevalenciji ovog problema tj. bihevioralne ovisnosti.

Također, utvrđivanje točnog udjela populacije koja je razvila ovaj problem otežava i činjenica da je ovisnost o Internetu vrlo često u komorbiditetu s drugim problemima mentalnog zdravlja, te njihova povezanost nije jednoznačna, što predstavlja izazov u odabiru i planiranju intervencija, odnosno otvara pitanje treba li se usmjeriti na problem mentalnog zdravlja u pozadini ovisnosti u Internetu ili, pak, osobu uputiti u ciljani tretman ovisnosti o Internetu.

Generalno, kako je riječ o relativno novom fenomenu, i prevalencijska, ali i istraživanja usmjerena etiologiji i fenomenologiji problema u svojim su počecima te je za pretpostaviti da je nužno određeno vrijeme da se korpus znanja u području proširi. Time će se stvoriti temelji za davanje odgovora na sve prethodno navedene izazove, a ti odgovori su nužni i u kontekstu razvoja intervencija na cijelom spektru.

Kada je riječ o (2) izazovima vezanima uz obilježja i dostupne spoznaje o učinkovitosti tretmana ovisnosti o Internetu, prije svega je nužno osvrnuti se na njihova metodološka ograničenja. Osim nedovoljnog broja empirijskih istraživanja učinkovitosti, u većini postojećih studija postoji samo intervencijska skupina, čime nije moguće donijeti pouzdane zaključke o samom tretmanu. Također, većina studija provedena je na malim i prigodnim uzorcima, bez dugoročnog i longitudinalnog praćenja, što onemogućava zaključivanje o efektima protekom vremena. Nadalje, ograničena je mogućnost usporedbe s obzirom na različite dijagnostičke kriterije i/ili instrumente procjene, a primijećen je i manjak detaljno opisanih intervencija (svega ih je nekoliko opisano po fazama i temama), što onemogućava replikaciju i evaluaciju programa na drugoj populaciji i zaključivanje o adekvatnosti sadržaja same intervencije. Kada je riječ o farmakoterapijskim tretmanskim pristupima, uočeno je da svi navedeni lijekovi još uvijek nisu dovoljno testirani da bi se moglo govoriti o njihovoj učinkovitosti i primarno su usmjereni na smanjenje simptoma drugih problema mentalnog zdravlja koji su u komorbiditetu s ovisnošću o Internetu.

Slijedom svih navedenih ograničenja i izazova prilikom istraživanja učinkovitosti tretmana ovisnosti o Internetu, ne čudi činjenica kako još uvijek nijedan tretmanski pristup ne zadovoljava kriterije za dobro uspostavljen ili vjerojatno učinkovit znanstveno-utemeljeni program prema kriterijima Chamblessa i suradnika (1998; prema Zajac i sur., 2017). 


\section{Zaključak}

U ovom je radu ponuđen sustavan i sveobuhvatan pregled i kritički osvrt na postojeće tretmanske pristupe ovisnosti o internetu, njihove terapijske temelje, te dostupne rezultate o učinkovitosti. Uz to, kritički su analizirani ključni izazovi tretmana, ali i konceptualni izazovi samog problema s obzirom da posredno utječu i na razvoj tretmanskih intervencija.

Neosporno je da dio populacije razvija probleme uslijed prekomjernog i nefunkcionalnog korištenja Interneta, te je nužno nastaviti s ulaganjem napora u kreiranje i evaluaciju intervencija usmjerenih ovom kompleksnom problemu. S tim ciljem, paralelno je potrebno poticati provedbu sustavnih i sveobuhvatnih empirijskih istraživanja o etiologiji i fenomenologiji ovisnosti o Internetu. Naime, takva su istraživanja nužna kako bi se postigao konsenzus oko jedinstvene definicije problema, pouzdanih kriterija i opće prihvaćene klasifikacije. Kada se zadovolje ti preduvjeti, omogućit će se i razvoj pouzdanih instrumenata procjene koji bi omogućavali usporedbu različitih populacija, adekvatno prepoznavanje pojedinaca kojima je tretman potreban, kao i praćenje učinaka intervencija.

Kada je riječ o potonjem, s obzirom da još uvijek ne postoje tretmanski programi koji zadovoljavaju kriterije učinkovitih programa, nužno je provoditi sveobuhvatne i kvalitetne evaluacijske studije kratkoročnih i dugoročnih učinaka intervencija. Navedene aktivnosti je moguće očekivati u daljnjem stručnom i znanstvenom radu u ovom dinamičnom području, čime će se stvoriti preduvjeti za prepoznavanje pojedinih pristupa kao znanstveno utemeljenih i učinkovitih, a sve s ciljem adekvatnog i uspješnog odgovora na ovu rastuću suvremenu bihevioralnu ovisnost.

\section{Literatura}

Achab, S., Simon, O., Müller, S., Thorens, G., Martinotti, G., Zullino, D., Khazaal, Y. (2015). Internet Addiction. U N. el-Guebaly, G. Carrà, M. Galanter (ur.), Textbook of Addiction Treatment: International Perspectives (str.1499-1513). Milano: Springer.

Aboujaoude, E., Koran, L.M., Gamel, N., Large, M.D., Serpe, R.T. (2006). Potential markers for problematic Internet use: A telephone survey of 2,513 adults. CNS Spectrum, 11: 750-755.

Akin, A., Iskender, M. (2011). Internet addiction and depression, anxiety, and stress. International Online Journal of Educational Sciences, 3 (1), 138-148.

Američka psihijatrijska udruga (2014). Dijagnostički i statistički priručnik za duševne poremećaje [DSM-5]. Urednici hrvatskog izdanja: Jukić, V. i Arbanas, G. Jastrebarsko: Naklada Slap.

Atmaca, M. (2007). A case of problematic internet use successfully treated with an SSRI-antipsychotic combination. Progress in Neuro-Psychopharmacology and Biological Psychiatry, 31 (4), 961-962. DOI:10.1016/j.pnpbp.2007.01.003

Bakken, I.J., Wenzel, H.G., Götestam, K.G., Johansson, A., Øren, A. (2009). Internet addiction among Norwegian adults: A stratified probability sample study. Scandinavian Journal of Psychology, 50 (2), 121-127. DOI: 10.1111/j.1467-9450.2008.00685.x

Balodis, I.M., Kober, H., Worhunsky, P.D., Stevens, M.C., Pearlson, G.D., Potenza, M. N. (2012). Diminished Frontostriatal Activity During Processing of Monetary Rewards and Losses in Pathological Gambling. Biological Psychiatry, 71 (8), 749-757. DOl:10.1016/j.biopsych.2012.01.006 
Bisen, S.S., Deshpande, Y. (2018). The Impact of the Internet in Twenty-First Century Addictions: An Overview. U B. Bozoglan (ur.), Psychological, Social and Cultural Aspects of Internet Addiction (str.1-19). Hershey, PA: IGI Global.

Blum, K., Oscar-Berman, M., Giordano, J., Downs, B., Simpatico, T., Han, D., Femino, J. (2012). Neurogenetic Impairments of Brain Reward Circuitry Links to Reward Deficiency Syndrome (RDS): Potential Nutrigenomic Induced Dopaminergic Activation. Journal of genetic syndromes \& gene therapy, 3 (4), 1000e115. DOI:10.4172/2157-7412.1000e115

Brand, M., Young, K.S., Laier, C. (2014a). Prefrontal control and Internet addiction: a theoretical model and review of neuropsychological and neuroimaging findings. Frontiers in Human Neuroscience, 8, 375. DOI: 10.3389/fnhum.2014.00375

Brand, M., Laier, C., Young, K.S. (2014b). Internet addiction: coping styles, expectancies, and treatment implications. Frontiers in Psychology, 5, 1256. DOI: 10.3389/fpsyg.2014.01256

Brand, M., Young, K.S., Laier, C., Wölfling, K., Potenza, M. (2016). Integrating psychological and neurobiological considerations regarding the development and maintenance of specific Internet-use disorders: An Interaction of Person-Affect-Cognition-Execution (I-PACE) model. Neuroscience and Biobehavioral Reviews, 71, 252-266. DOI: 10.1016/j.neubiorev.2016.08.033

Bystritsky, A., Ackerman, D.L., Rosen, R.M., Vapnik, T., Gorbis, E., Maidment, K.M., Saxena, S. (2004). Augmentation of Serotonin Reuptake Inhibitors in Refractory Obsessive-Compulsive Disorder Using Adjunctive Olanzapine. The Journal of Clinical Psychiatry, 65 (4), 565568. DOI: 10.4088/JCP.v65n0418

Caldiroli, A., Serati, M., Buoli, M. (2018). Is Internet Addiction a Clinical Symptom or a Psychiatric Disorder? A Comparison With Bipolar Disorder. The Journal of Nervous and Mental Disease, 1. DOI:10.1097/nmd.0000000000000861

Camardese, G., De Risio, L., Di Nicola, M., Pizi, G., Janiri, L. (2012). A Role for Pharmacotherapy in the Treatment of "Internet Addiction". Clinical Neuropharmacology, 35 (6), 283-289. DOI:10.1097/wnf.0b013e31827172e5

Camardese, G., Leone, B., Walstra, C., Janiri, L., Guglielmo, R. (2015). Pharmacological Treatment of Internet Addiction. U C. Montag, M. Reuter (ur.), Internet Addiction: Neuroscientific Approaches and Therapeutical Interventions (str.151-165). Springer.

Cao, H., Sun, Y., Wan, Y., Hao, J., Tao, F. (2011). Problematic Internet use in Chinese adolescents and its relation to psychosomatic symptoms and life satisfaction. BMC Public Health, 11, 1. DOI: $10.1186 / 1471-2458-11-802$

Carli, V., Durkee, T., Wasserman, D., Hadlaczky, G., Despalins, R., Kramarz, E., Wasserman, C., Sarchiapone, M., Hoven, C.W., Brunner, R., Kaess, M. (2013). The Association between Pathological Internet Use and Comorbid Psychopathology: A Systematic Review. Psychopathology, 46 (1), 1-13. DOI: 10.1159/000337971

Cash, H., Rae, C.D., Steel, A.H., Winkler, A. (2012). Internet Addiction: A Brief Summary of Research and Practice. Current psychiatry reviews, 8, 4, 292-298. DOI: 10.2174/157340012803520513

Cimino, S., Cerniglia, L. (2018). A Longitudinal Study for the Empirical Validation of an Etiopathogenetic Model of Internet Addiction in Adolescence Based on Early Emotion Regulation. BioMed Research International, 1-8. DOI: 10.1155/2018/4038541

Davis, R.A. (2001). A cognitive-behavioral model of pathological Internet Use. Computers in Human Behavior, 17, 187-195. DOI: 10.1016/S0747-5632(00)00041-8 
Dell'Osso, B., Hadley, S., Allen, A., Baker, B., Chaplin, W.F., Hollander, E. (2008). Escitalopram in the treatment of impulsive-compulsive internet usage disorder: an open-label trial followed by a double-blind discontinuation phase. Journal of clinical psychiatry, 69 (3), 452-456.

Denys, D., de Geus, F., van Megen, H.J., Westenberg, H.G. (2004). A double-blind, randomized, placebo-controlled trial of quetiapine addition in patients with obsessive-compulsive disorder refractory to serotonin reuptake inhibitors. The Journal of Clinical Psychiatry, 65 (8), 1040-1048.

Dichiara, G., Bassareo, V. (2007). Reward system and addiction: what dopamine does and doesn't do. Current Opinion in Pharmacology, 7 (1), 69-76. DOI: 10.1016/j.coph.2006.11.003

Dodig Hundrić, D., Ricijaš, N., Vlček, M. (2018). Mladi i ovisnost o internetu - pregled suvremenih spoznaja. Hrvatska revija za rehabilitacijska istraživanja, 54 (1), 123-137.

Du, Y., Jiang, W., Vance, A. (2010). Longer Term Effect of Randomized, Controlled Group Cognitive Behavioural Therapy for Internet Addiction in Adolescent Students in Shanghai. Australian \& New Zealand Journal of Psychiatry, 44 (2), 129-134. DOI:10.3109/00048670903282725

Eliacik, K., Bolat, N., Koçyiğit, C., Kanik, A., Selkie, E., Yilmaz, H., Catli, G., Dundar, N.O., Dundar, B.N. (2016). Internet addiction, sleep and health-related life quality among obese individuals: a comparison study of the growing problems in adolescent health. Eating and Weight Disorders-Studies on Anorexia, Bulimia and Obesity, 21 (4), 709-717. DOI:10.1007/ s40519-016-0327-z

Fairburn, C.G., Patel, V. (2017). The impact of digital technology on psychological treatments and their dissemination. Behaviour research and therapy, 88, 19-25. DOI:10.1016/j. brat.2016.08.012

Flisher, C. (2010). Getting plugged in: An overview of Internet addiction. Journal of Paediatrics and Child Health, 46 (10), 557-559. DOI:10.1111/j.1440-1754.2010.01879.x

Fortson, B.L., Scotti, J.R., Chen, Y.-C., Malone, J., Del Ben, K.S. (2007). Internet Use, Abuse, and Dependence Among Students at a Southeastern Regional University. Journal of American College Health, 56 (2), 137-144. DOI: 10.3200/jach.56.2.137-146

Goldberg, J.F., Whiteside, J.E., (2002). The association between substance abuse and antidepressant-induced mania in bipolar disorder: a preliminary study. Journal of clinical psychiatry, 63 (9), 791-795.

Grant, J.E., Chamberlain, S.R., Odlaug, B.L., Potenza, M.N., Kim, S.W. (2010). Memantine shows promise in reducing gambling severity and cognitive inflexibility in pathological gambling: a pilot study. Psychopharmacology, 212 (4), 603-612. DOI:10.1007/s00213-010-1994-5

Greenfield, D.N. (2018). Treatment Considerations in Internet and Video Game Addiction: A qualitative discussion. Child and Adolescent Psychiatric Clinics of North America, 27 (2), 327-344. DOI:10.1016/j.chc.2017.11.007

Griffiths, M.D. (2005). A 'components' model of addiction within a biopsychosocial framework. Journal of Substance Use, 10 (4), 191-197. DOI: 10.1080/14659890500114359

Ha, J.H., Yoo, H.J., Cho, I.H., Chin, B., Shin, D., Kim, J.H. (2006). Psychiatric Comorbidity Assessed in Korean Children and Adolescents Who Screen Positive for Internet Addiction. The Journal of Clinical Psychiatry, 67 (5), 821-826. DOI: 10.4088/JCP.v67n0517

Han, D.H., Lee, Y.S., Na, C., Ahn, J.Y., Chung, U.S., Daniels, M.A., Haws, C.A., Renshaw, P.F. (2009). The effect of methylphenidate on Internet video game play in children with attention-de- 
ficit/hyperactivity disorder. Comprehensive Psychiatry, 50 (3), 251-256. DOI:10.1016/j. comppsych.2008.08.011

Han, D.H., Renshaw, P.F. (2012). Bupropion in the treatment of problematic online game play in patients with major depressive disorder. Journal of Psychopharmacology, 26 (5), 689696. DOI:10.1177/0269881111400647

Hollander, E., Rossi, N.B., Sood, E., Pallanti, S. (2003). Risperidone augmentation in treatment-resistant obsessive-compulsive disorder: a double-blind, placebo-controlled study. The International Journal of Neuropsychopharmacology, 6 (4), 397-401. DOI:10.1017/ s1461145703003730

Huang, X., Li, M., Tao, R. (2010). Treatment of Internet Addiction. Current Psychiatry Reports, 12 (5), 462-470. DOI:10.1007/s11920-010-0147-1

International Classification of Diseases 11th Revision. Posjećeno 10.05.2019. na mrežnoj stranici: https://icd.who.int/browse11/l-m/en\#/http\%3a\%2f\%2fid.who.int\%2ficd\%2fentity\%2f1448597234

Jäger, S., Müller, K.W., Ruckes, C., Wittig, T., Batra, A., Musalek, M., Mann, K., Wölfling, K., Beutel, M.E. (2012). Effects of a manualized short-term treatment of internet and computer game addiction (STICA): study protocol for a randomized controlled trial. Trials, 13, 43. DOI:10.1186/1745-6215-13-43

Jurman, J., Boričević Maršanić, V., Paradžik, Lj., Karapetrić Bolfan, Lj., Javornik, S. (2017). Ovisnost o internetu i video igrama. Socijalna psihijatrija, 45 (1), 36-42.

Kim, J.-U. (2007). A Reality Therapy Group Counseling Program as An Internet Addiction Recovery Method for College Students in Korea. International Journal of Reality Therapy, 26 (2), 3-9.

Kim, J.-U. (2008). The Effect of a R/T Group Counseling Program on The Internet Addiction Level and Self-Esteem of Internet Addiction University Students. International Journal of Reality Therapy, 27 (2), 4-12.

Kim, S.M., Han, D.H., Lee, Y.S., Renshaw, P.F. (2012). Combined cognitive behavioral therapy and bupropion for the treatment of problematic on-line game play in adolescents with major depressive disorder. Computers in Human Behavior, 28 (5), 1954-1959. DOI:10.1016/j.chb.2012.05.015

King, D.L., Delfabbro, P.H., Griffiths, M.D., Gradisar, M. (2012). Cognitive-Behavioral Approaches to Outpatient Treatment of Internet Addiction in Children and Adolescents. Journal of Clinical Psychology, 68 (11), 1185-1195. DOI:10.1002/jclp.21918

Ko, C.-H., Liu, G.-C., Hsiao, S., Yen, J.-Y., Yang, M.-J., Lin, W.-C., Yen, C.-F., Chen, C.-S. (2009). Brain activities associated with gaming urge of online gaming addiction. Journal of Psychiatric Research, 43 (7), 739-747. DOI:10.1016/j.jpsychires.2008.09.012

Ko, C.-H., Yen, J.-Y., Yen, C.-F., Chen, C.-S., Chen, C.-C. (2012). The association between Internet addiction and psychiatric disorder: A review of the literature. European Psychiatry, 27 (1), 1-8. DOI: 10.1016/j.eurpsy.2010.04.011

Kuss, D., Griffiths, M. (2017). Social Networking Sites and Addiction: Ten Lessons Learned. International Journal of Environmental Research and Public Health, 14 (3), 311. DOI: 10.3390/ ijerph14030311

Kuss, D.J. (2016). Internet Addiction: The Problem and Treatment. Addicta: The Turkish Journal on Addictions, 3 (2), 185-192. DOI:10.15805/addicta.2016.3.0106 
Sabina Mandić, Dora Dodig Hundrić, Neven Ricijaš: Tretmanski pristupi ovisnosti o Internetu

Kuss, D.J., Griffiths, M.D., Binder, J.F. (2013). Internet addiction in students: Prevalence and risk factors. Computers in Human Behavior, 29 (3), 959-966. DOI: 10.1016/j.chb.2012.12.024

Kuss, D.J., Lopez-Fernandez, O. (2016). Internet addiction and problematic Internet use: A systematic review of clinical research. World journal of psychiatry, 6 (1), 143-176. DOI: 10.5498/ wjp.v6.i1.143

Kuss, D.J., Pontes, H.M. (2019). Internet Addiction. Boston: Hogrefe Publishing.

Laconi, S., Kaliszewska-Czeremska, K., Gnisci, A., Sergi, I., Barke, A., Jeromin, F., Groth, J., Gamez-Guadix, M., Ozcan, N.K., Demetrovics, Z., Kiraly, O., Siomos, K., Floros, G., Kuss, D.J. (2018). Cross-cultural study of Problematic Internet Use in nine European countries. Computers in Human Behavior, 84, 430-440. DOI:10.1016/j.chb.2018.03.020

Li, G., Hou, G., Yang, D., Jian, H., Wang, W. (2019). Relationship between anxiety, depression, sex, obesity, and internet addiction in Chinese adolescents: A short-term longitudinal study. Addictive Behaviors, 90, 421-427. DOI:10.1016/j.addbeh.2018.12.009

Liu, J., Gao, X.P., Osunde, I., Li, X., Zhou, S.K., Zheng, H.R., Li, L.J. (2010). Increased regional homogeneity in internet addiction disorder: a resting state functional magnetic resonance imaging study. Chinese medical journal, 123 (14), 1904-1908.

Liu, Q.-X., Fang, X.-Y., Yan, N., Zhou, Z.-K., Yuan, X.-J., Lan, J., Liu, C.-Y. (2015). Multi-family group therapy for adolescent Internet addiction: Exploring the underlying mechanisms. Addictive Behaviors, 42, 1-8. DOI:10.1016/j.addbeh.2014.10.021

Luo, S.X., Brennan, T.K., Wittenauer, J. (2015). Internet Addiction: The case of Henry, the „Reluctant Hermit". U M.S. Ascher, P. Levounis (ur.), The Behavioral Addictions (str.81-101). Washington, DC: American Psychiatric Publishing.

Maina, G., Pessina, E., Albert, U., Bogetto, F. (2008). 8-week, single-blind, randomized trial comparing risperidone versus olanzapine augmentation of serotonin reuptake inhibitors in treatment-resistant obsessive-compulsive disorder. European Neuropsychopharmacology, 18 (5), 364-372. DOI:10.1016/j.euroneuro.2008.01.001

Malak, M.Z. (2018). Internet Addiction and Cognitive Behavioral Therapy. Cognitive Behavioral Therapy and Clinical Applications. DOI:10.5772/intechopen.71277

Mihajlov, M., Vejmelka, L. (2017). Internet Addiction: A Review of the First Twenty Years. Psychiatria Danubina, 29 (3), 260-272. DOI: 10.24869/psyd.2017.260

Montag, C., Bey, K., Sha, P., Li, M., Chen, Y.F., Liu, W.Y., Zhu, Y.K., Li, C.B., Markett, S., Keiper, J., Reuter, M. (2015). Is it meaningful to distinguish between generalized and specific Internet addiction? Evidence from a cross-cultural study from Germany, Sweden, Taiwan and China. Asia-Pacific Psychiatry, 7 (1), 20-26. DOI: 10.1111/appy.12122

Montag, C., Reuter, M., Markowetz, A. (2015). The Impact of Psychoinformatics on Internet Addiction. U C. Montag, M. Reuter (ur.), Internet Addiction: Neuroscientific Approaches and Therapeutical Interventions (str.143-150). Springer.

Orzack, M.H., Voluse, A.C., Wolf, D., Hennen, J. (2006). An Ongoing Study of Group Treatment for Men Involved in Problematic Internet-Enabled Sexual Behavior. CyberPsychology \& Behavior, 9 (3), 348-360. DOI:10.1089/cpb.2006.9.348

Pallanti, S., Quercioli, L., Sood, E., Hollander, E. (2002). Lithium and valproate treatment of pathological gambling: a randomized single-blind study. The Journal of Clinical Psychiatry, 63 (7), 559-564. DOI: 10.4088/JCP.v63n0704 
Park, S.Y., Kim, S.M., Roh, S., Soh, M.-A., Lee, S.H., Kim, H., Lee, Y.S., Han, D.H. (2016). The effects of a virtual reality treatment program for online gaming addiction. Computer Methods and Programs in Biomedicine, 129, 99-108. DOI:10.1016/j.cmpb.2016.01.015

Pearson, F.S., Prendergast, M.L., Podus, D., Vazan, P., Greenwell, L., Hamilton, Z. (2012). Meta-analyses of seven of the National Institute on Drug Abuse's principles of drug addiction treatment. Journal of substance abuse treatment, 43 (1), 1-11. DOI:10.1016/j.jsat.2011.10.005

Poli, R., Agrimi, E. (2011). Internet addiction disorder: Prevalence in an Italian student population. Nordic Journal of Psychiatry, 66 (1), 55-59. DOI: 10.3109/08039488.2011.605169

Pontes, H.M., Kuss, D.J., Griffiths, M.D. (2015). Clinical psychology of internet addiction: a review of its conceptualization, prevalence, neuronal processes, and implications for treatment. Neuroscience and Neuroeconomics, 4, 11-23. DOI:10.2147/NAN.S60982

Prizant-Passal, S., Shechner, T., Aderka, I.M. (2016). Social anxiety and internet use - A meta-analysis: What do we know? What are we missing?. Computers in Human Behavior, 62, 221-229. DOI: 10.1016/j.chb.2016.04.003

Przepiorka, A.M., Blachnio, A., Miziak, B., Czuczwar, S.J. (2014). Clinical approaches to treatment of Internet addiction. Pharmacological Reports, 66 (2), 187-191. DOI:10.1016/j.pharep.2013.10.001

Rębisz, S., Sikora, I. (2016). Internet Addiction in Adolescents. Practice and Theory in Systems of Education, 11 (3), 194-204. DOI: 10.1515/ptse-2016-0019

Rich, M., Tsappis, M., Kavanaugh, J.R. (2017). Problematic Interactive Media Use Among Children and Adolescents: Addiction, Compulsion, or Syndrome? U K.S. Young, C. Nabuco de Abreu (ur.), Internet Addiction in Children and Adolescents - Risk Factors, Assessment, and Treatment (str.3-28). New York: Springer Publishing Company.

Richards, D. (2013). Developments in technology-delivered Psychological interventions. Universitas Psychologica, 12 (2), 571-579.

Rowicka, M. (2016). Internet addiction treatment. U B. Lelonek-Kuleta, J. Chwaszcz (ur.), Gambling and Internet addictions - epidemiology and treatment (str.55-65). Natanaelum Association Institute for Psychoprevention and Psychotherapy, Lublin.

Rumpf, H.-J., Tao, R., Rehbein, F., Petry, N.M. (2016). Internet Addiction - A Future Addictive Disorder?. U N.M. Petry (ur.), Behavioral Addictions: DSM-5 and Beyond (str.71-99). Oxford University Press.

Rumpf, H.-J., Vermulst, A.A., Bischof, A., Kastirke, N., Gürtler, D., Bischof, G., Meerkerk, G.-J., John, U., Meyer, C. (2014). Occurence of Internet Addiction in a General Population Sample: A Latent Class Analysis. European Addiction Research, 20 (4), 159-166. DOI: $10.1159 / 000354321$

Santos, V.A., Freire, R., Zugliani, M., Cirillo, P., Santos, H.H., Nardi, A.E., King, A.L. (2016). Treatment of Internet Addiction with Anxiety Disorders: Treatment Protocol and Preliminary Before-After Results Involving Pharmacotherapy and Modified Cognitive Behavioral Therapy. JMIR research protocols, 5 (1), e46. DOI:10.2196/resprot.5278

Santos, V., Freire, R., Zugliani, M., Cirillo, P., Santos, H.H.K., Nardi, A.E., King, A.L.S. (2017). Treatment outcomes in patients with Internet Addiction and anxiety. MedicalExpress, 4, 2: M170206. DOI: 10.5935/MedicalExpress.2017.02.06 
Sariyska, R., Reuter, M., Bey, K., Sha, P., Li, M., Chen, Y.-F., ... Montag, C. (2014). Self-esteem, personality and Internet Addiction: A cross-cultural comparison study. Personality and Individual Differences, 61-62, 28-33. DOI: 10.1016/j.paid.2014.01.001

Seyrek, S., Cop, E., Sinir, H., Ugurlu, M., Şenel, S. (2016). Factors associated with Internet addiction: Cross-sectional study of Turkish adolescents. Pediatrics International, 59 (2), 218-222. DOI: $10.1111 /$ ped.13117

Shad Kaneez, F., Zhu, K., Tie, L., Osman, N.B.H. (2013). Is Cognitive Behavioral Therapy an Intervention for Possible Internet Addiction Disorder?. Journal of Drug and Alcohol Research, 2, 1-9. DOI:10.4303/jdar/235819

Sharma, P., De Sousa, A. (2016). Internet Addiction in adolescents - an overview. Indian Journal of Mental Health, 3 (4), 394-404. DOI: 10.30877/IJMH.3.4.2016.394-404

Shek, D.T., Tang, V.M., Lo, C.Y. (2009). Evaluation of an Internet addiction treatment program for Chinese adolescents in Hong Kong. Adolescence, 44 (174), 359-373.

Shek, D.T., Yu, L., Sun, R.C. (2016). Internet addiction. Neuroscience in the 21st century, 1-44.

Shen, L. (2018). Treatment of Internet Addiction. U B. Bozoglan (ur.), Psychological, Social and Cultural Aspects of Internet Addiction (str.284-310). Hershey, PA: IGI Global.

Słowiński, T., Stefanowicz, J., Dawidowski, M., Kleps, J., Czuczwar, S., Andres-Mach, M., Łuszczki, J.J., Nowak, G., Stachowicz, K., Szewczyk, B., Sławińska, A., Mazurek, A.P., Mazurek, A., Pluciński, F., Wolska, I., Herold, F. (2011). Synthesis and biological investigation of potential atypical antipsychotics with a tropane core. Part 1. European journal of medicinal chemistry, 46 (9), 4474-4488. DOI: 10.1016/j.ejmech.2011.07.022

Smyth, S.J., Curran, K., Mc Kelvey, N. (2018). Internet Addiction: A Modern Societal Problem. U B. Bozoglan (ur.), Psychological, Social and Cultural Aspects of Internet Addiction (str.2043). Hershey, PA: IGI Global.

Starcevic, V. (2013). Is Internet addiction a useful concept?. Australian \& New Zealand Journal of Psychiatry, 47 (1), 16-19. DOI: 10.1177/0004867412461693

Stone, R. (2009). China Reins in Wilder Impulses in Treatment of "Internet Addiction". Science, 324 (5935), 1630-1631. DOI:10.1126/science.324_1630

Torres-Rodríguez, A., Carbonell, X. (2017). Update and proposal of treatment for Internet Gaming Disorder: PIPATIC program. Revista de psicoterapia, 28 (107), 317-336.

Torres-Rodríguez, A., Griffiths, M.D., Carbonell, X. (2018). The Treatment of Internet Gaming Disorder: a Brief Overview of the PIPATIC Program. International Journal of Mental Health and Addiction, 16 (4), 1000-1015. DOI:10.1007/s11469-017-9825-0

Torres-Rodríguez, A., Griffiths, M.D., Carbonell, X., Farriols-Hernando, N., Torres-Jimenez, E. (2017). Internet Gaming Disorder Treatment: A Case Study Evaluation of Four Different Types of Adolescent Problematic Gamers. International Journal of Mental Health and Addiction. DOI:10.1007/s11469-017-9845-9

Vondrackova, P., Šmahel, D. (2018). Internet Addiction in Context. U M. Khosrow-Pour (ur.), Encyclopedia of Information Science and Technology, Fourth Edition (str. 4223 - 4233). Hershey, PA: IGI Global.

Weinstein, A., Lejoyeux, M. (2010). Internet Addiction or Excessive Internet Use. The American Journal of Drug and Alcohol Abuse, 3 (5), 277-283. DOI: 10.3109/00952990.2010.491880 
Weiser, E.B. (2001). The Functions of Internet Use and Their Social and Psychological Consequences. Cyberpsychology \& Behavior, 4 (6), 723-743.

Winkler, A., Dörsing, B., Rief, W., Shen, Y., Glombiewski, J. A. (2013). Treatment of internet addiction: A meta-analysis. Clinical Psychology Review, 33 (2), 317-329. DOI:10.1016/j. cpr.2012.12.005

Wölfling, K., Beutel, M.E., Dreier, M., Müller, K.W. (2014). Treatment Outcomes in Patients with Internet Addiction: A Clinical Pilot Study on the Effects of a Cognitive-Behavioral Therapy Program. BioMed Research International, 2014, 1-8. DOI:10.1155/2014/425924

Yen, J.-Y., Ko, C.-H., Yen, C.-F., Wu, H.-Y., Yang, M.-J. (2007a). The Comorbid Psychiatric Symptoms of Internet Addiction: Attention Deficit and Hyperactivity Disorder (ADHD), Depression, Social Phobia, and Hostility. Journal of Adolescent Health, 41 (1), 93-98. DOI:10.1016/j. jadohealth.2007.02.002

Yen, J.-Y., Yen, C.-F., Chen, C.-C., Chen, S.-H., Ko, C.-H. (2007b). Family Factors of Internet Addiction and Substance Use Experience in Taiwanese Adolescents. CyberPsychology \& Behavior, 10 (3), 323-329. DOI:10.1089/cpb.2006.9948

Young, K.S. (1996). Internet addiction: The emergence of a new clinical disorder. Paper presented at the 104th annual meeting of the American Psychological Association, 11. kolovoza 1996. Toronto, Canada.

Young, K.S. (1999). Internet Addiction: Symptoms, Evaluation, and Treatment. U L. VandeCreek, T.L. Jackson (ur.), Innovations in Clinical Practice (volume 17) (str.19-31). Sarasota, FL: Professional Resource Press.

Young, K.S. (2004). Internet Addiction: A New Clinical Phenomenon and Its Consequences. American Behavioral Scientist, 48 (4), 402-415. DOI: 10.1177/0002764204270278

Young, K.S. (2007). Cognitive Behavior Therapy with Internet Addicts: Treatment Outcomes and Implications. CyberPsychology \& Behavior, 10 (5), 671-679. DOI:10.1089/cpb.2007.9971

Young, K.S. (2011a). CBT-IA: The First Treatment Model for Internet Addiction. Journal of Cognitive Psychotherapy, 25 (4), 304-312. DOI:10.1891/0889-8391.25.4.304

Young, K.S. (2011b). Clinical assessment of Internet-addicted clients. Internet addiction: A handbook and guide to evaluation and treatment, 19-34.

Young, K.S. (2013). Treatment outcomes using CBT-IA with Internet-addicted patients. Journal of Behavioral Addictions, 2 (4), 209-215. DOI:10.1556/jba.2.2013.4.3

Young, K.S. (2015). The Evolution of Internet Addiction Disorder. U C. Montag, M. Reuter (ur.), Internet Addiction. Studies in Neuroscience, Psychology and Behavioral Economics (str. 3-17). Springer, Cham. DOI: 10.1007/978-3-319-07242-5_1

Zajac, K., Ginley, M.K., Chang, R., Petry, N.M. (2017). Treatments for Internet Gaming Disorder and Internet Addiction: A Systematic Review. Psychology of Addictive Behaviors, 31(8), 979-994. doi: 10.1037/adb0000315

Zhang, M.W.B., Ho, R.C.M. (2017). Smartphone applications for immersive virtual reality therapy for internet addiction and internet gaming disorder. Technology and Health Care, 25 (2), 367-372. DOI:10.3233/thc-161282

Zhou, Z., Zhou, H., Zhu, H. (2016). Working memory, executive function and impulsivity in Internet-addictive disorders: a comparison with pathological gambling. Acta Neuropsychiatrica, 28 (2), 92-100. DOI:10.1017/neu.2015.54 
Sabina Mandić

Dora Dodig Hundrić

Neven Ricijaš

Department of Behavioral Disorders,

Faculty of Education and Rehabilitation Sciences, University of Zagreb

\title{
Treatment approaches for Internet addiction
}

\begin{abstract}
In contemporary world, the Internet seems omnipresent and often indispensable. It is also a mean of meeting psychological needs and represents an integral part of modern communication. Therefore, it is not surprising that a certain part of the population develops problems associated with excessive Internet use, which can lead to addiction.

Since there are no unambiguous definition for this problem or precise indicators of prevalence and incidence, the Internet addiction is not yet listed as a separate diagnostic entity in international classifications of mental health problems. However, its undisputed current relevance and prevalence of this problem have led to the need for the development of treatment interventions.

In the absence of domestic literature in this area, the main purpose of this paper is to provide a systematic and comprehensive overview of the literature on existing Internet addiction treatment approaches, their therapeutic foundations, key treatment challenges and available research findings on their effectiveness.

In conclusion, the authors reflect on current conceptual and research challenges which represent obstacles to the development of treatment interventions and the conclusion about their effectiveness.
\end{abstract}

Keywords: Internet, Internet addiction, behavioral addiction, treatment 